\title{
SULPHOBROMOPHTHALEIN RETENTION IN GOUT AND ASYMPTOMATIC HYPERURICAEMIA*
}

BY

\author{
R. GRAHAME $\dagger$, R. M. HASLAM, AND J. T. SCOTT $\ddagger$
}

From the Departments of Medicine and Chemical Pathology, Royal Postgraduate Medical School of London

In a recent study comparing the clinical effects of allopurinol with those of probenecid in the treatment of gout (Scott, Hall, and Grahame, 1966), a high incidence of abnormal sulphobromophthalein (BSP) retention was found in patients taking both drugs. This unexpected finding has now been further investigated.

\section{Methods}

BSP excretion tests were performed on 73 patients with gout (defined as recurrent acute arthritis associated with an elevated serum uric acid level), ${ }^{*}$ sixteen patients with asymptomatic hyperuricaemia not due to renal failure, and thirty control subjects who were either hospital patients (none of whom had known liver disease, gout, or hyperuricaemia) or healthy volunteers. The details of the patients and controls are shown in Table $I$.

* For the purpose of this study the upper limit of normal for serum uric acid by the method used (Technicon Auto-analyser) is taken to be $7 \mathrm{mg} . / 100 \mathrm{ml}$. for men and post-menopausal women and $6 \mathrm{mg} . / 100 \mathrm{ml}$. for pre-menopausal women.

TABLE I

PARTICULARS OF PATIENTS AND CONTROLS

\begin{tabular}{|c|c|c|c|c|}
\hline Series $\ldots$ & .. & $\begin{array}{l}\text { Patients } \\
\text { with } \\
\text { Gout }\end{array}$ & $\begin{array}{c}\text { Patients with } \\
\text { Asymptomatic } \\
\text { Hyperuricaemia }\end{array}$ & $\begin{array}{l}\text { Control } \\
\text { Subjects }\end{array}$ \\
\hline Number & & 73 & 16 & 30 \\
\hline Females & & 5 & 2 & 11 \\
\hline Age (yrs) & $\begin{array}{l}\text { Mean } \\
\text { Range }\end{array}$ & $\begin{array}{c}55 \\
27-80\end{array}$ & $\begin{array}{c}40 \\
13-65\end{array}$ & $\begin{array}{c}48 \\
18-72\end{array}$ \\
\hline \multicolumn{2}{|c|}{ Overt Liver Disease } & $\mathbf{0}$ & 0 & 0 \\
\hline \multicolumn{2}{|c|}{ Past History of Hepatitis } & 2 & $\mathbf{0}$ & 0 \\
\hline \multicolumn{2}{|c|}{ Regular Drinkers* } & 24 & 3 & 0 \\
\hline $\begin{array}{l}\text { Serum Uric } \\
\text { Acid }\end{array}$ & $\begin{array}{l}\text { Mean } \\
\text { Range }\end{array}$ & $\begin{array}{r}6 \cdot 8 \dagger \\
3 \cdot 1-11 \cdot 7\end{array}$ & $\begin{array}{c}7 \cdot 7 \\
7 \cdot 1-10 \cdot 2\end{array}$ & $\begin{array}{r}4 \cdot 4 \\
2 \cdot 9-6 \cdot 7\end{array}$ \\
\hline \multicolumn{2}{|c|}{$\begin{array}{l}10 \text { per cent. or more } \\
\text { above Ideal Weight }\end{array}$} & 32 & 7 & 11 \\
\hline
\end{tabular}

*Defined as those whose average daily intake is two pints of beer or two double whiskies or more.

tApproximately $2 / 3$ of these patients were receiving long-term treatment aimed at lowering the serum uric acid level.

${ }^{*}$ Presented at a meeting of the Herberden Society on March 17 , 1967.

†resent address for reprints: Kennedy Institute of Rheumatology,

Bute Gardens, London, W.6.

$\ddagger$ Now Consultant Physician, Charing Cross and West London Hospitals.
To perform the BSP test a dose of $5 \mathrm{mg} . / \mathrm{kg}$. body weight was injected intravenously and a single specimen of blood withdrawn from the opposite arm 45 minutes later. For estimation of BSP $2 \mathrm{ml}$. serum were mixed with $3 \mathrm{ml} .0 .05 N \mathrm{NaOH}$ and a reading was taken in a colorimeter with an Ilford 624 filter (test). The mixture was then acidified with 2 drops of concentrated $\mathrm{HCl}$ (to discharge the colour of the BSP) and re-read (control). The BSP concentration was calculated by comparing the difference between these two readings with that of a standard solution of BSP. Results were expressed as the percentage retention of BSP at 45 minutes on the basis of an initial plasma concentration of $10 \mathrm{mg} . / 100 \mathrm{ml}$., assuming a direct relationship (of $50 \mathrm{ml} . / \mathrm{kg}$.) between plasma volume and body weight (see below).

All patients were kept fasting overnight for the test to avoid lipaemic specimens. Occasionally, turbidities were encountered which invalidated results and these were discarded. (Any error in this method due to turbidities tends towards low rather than high results.) $\dagger$

The upper limit of normal of BSP retention at 45 minutes is generally regarded to be between 3 and 5 per cent. (Sherlock, 1963; Henry, 1964; Cohn, 1965). Any level higher than 5 per cent. was therefore classified for the purposes of the present investigation as abnormal.

No serious reactions to the injected dye were encountered, but three patients experienced transient vasovagal symptoms, one noticed transient malaise, and in one case local erythema during the injection led to its abandonment.

Other liver function tests performed on all subjects consisted of serum bilirubin, alkaline phosphatase, total protein, albumin/globulin ratio, and isocitric dehydrogenase (ICD) (Bell and Baron, 1960) estimations.

An attempt was also made to assess the effect on liver function tests of temporarily raising the serum uric acid in healthy subjects. This was done by the oral administration of capsules containing ribonucleic acid (RNA) derived from yeast (Nugent and Tyler, 1959). Serum uric acid, BSP, ICD, and alkaline phosphatase estimations were performed on five healthy volunteers before

†An improved method for BSP estimation (Seligson, Marino, and Dodson, 1957) is now in routine use in our laboratory in which changes in $\mathrm{pH}$ are reduced and controlled and turbidity errors are less. Since this study was started on the older method, it has been continued throughout, but many comparisons have shown only minor differences in results between the two methods $(0-1$ per cent. retention) except in cases of lipaemia or haemolysis. 
and after the ingestion of RNA taken in a dosage of 1.5 g. 6 -hrly over 48 hours. In two subjects (1 and 2$)$ the tests were also repeated 4 days after completing the course of RNA. The sixth subject, who was a patient suffering from rheumatoid arthritis, agreed to take the RNA capsules for a period of one week and the tests were performed before, during, and after this period of study.

\section{Results}

The mean BSP retention in the patients with gout was $9 \cdot 2$ per cent. (range 2-27) and in 55 out of 73 (75 per cent.) it was greater than 5 per cent. The mean BSP retention in the patients with asymptomatic hyperuricaemia was $7 \cdot 1$ per cent. (range $2-12$ ) and in twelve out of sixteen it was greater than 5 per cent. In the control group the mean BSP was 3.5 per cent. (range $0-10$ ), and in six out of thirty (20 per cent.) it was greater than 5 per cent. (Fig. 1). The differences between the control group and the other two groups are statistically significant $\mathbf{P}<0.001$.

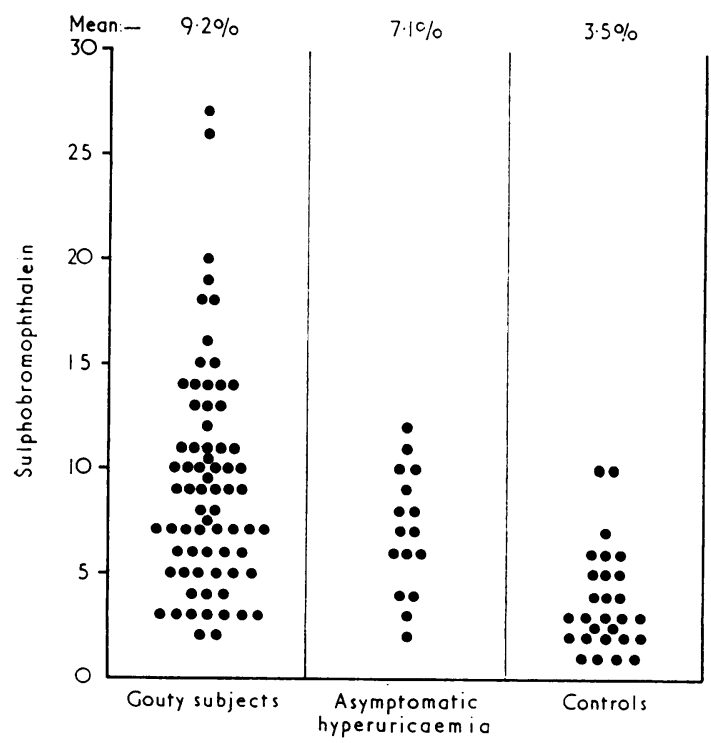

Fig. 1.-Scatter diagram of BSP results in gouty, asymptomatic hyperuricaemic, and control subjects.
Abnormalities in the gouty subjects occurreof irrespective of treatment (Table II). The highesE mean value of BSP retention was found in the untreated group and the lowest in allopurinolw. treated patients, but these differences do not achieve statistical significance.

Results were also analysed for duration of disease, sex, level of diastolic blood pressure (currene or mean value), level of serum uric acid (pre-treat $\frac{\bar{\omega}}{5}$. ment or current value), and the administration of colchicine, but these factors were found to have now influence on BSP excretion.

It did appear, however, that three other factors $\vec{\rho}$ (weight, alcohol consumption, and age) might have influenced these results and these factors are nowe considered in further detail.

\section{(A) Weight}

Gouty subjects tend to be overweight (Brøchner윽 Mortensen, 1941). The mean weight of the goutyand asymptomatic hyperuricaemic patients in the present study was 80 and $78 \mathrm{~kg}$. respectively? compared with $70 \mathrm{~kg}$. for the controls.

There appear to be two ways in which results of BSP tests can be affected by obesity: many obese subjects have fatty infiltration of the liver am do impaired liver function (Zelman, 1952), and 8 error can arise from the assumption of a dires linear relationship between plasma volume and body weight. In fact, however, this is not the case, plasmæ volume being relatively smaller in heavier subjects (Gibson and Evans, 1937). It therefore follows that $\overrightarrow{\vec{B}}$ in the standard procedure, overweight subjects ares given a relatively high dose in relation to their? plasma volume. Conversely, underweight subjectș. receive a relatively small dose. On the basis of 718 BSP estimations in normal male subjects, Zieve and Hill (1955) calculated an approximate correction tơ the BSP result. They suggested that with weightsbetween 110 and $149 \mathrm{lb} .1$ per cent. should be added? to BSP result; between 150 and $169 \mathrm{lb}$. no correction was necessary; between 170 and $189 \mathrm{lb} .1$ per cent. should be subtracted; and between 190 and $209 \mathrm{lb}>$ 3 per cent. should be subtracted. Applying this

TABLE II

FINDINGS IN 73 GOUTY PATIENTS

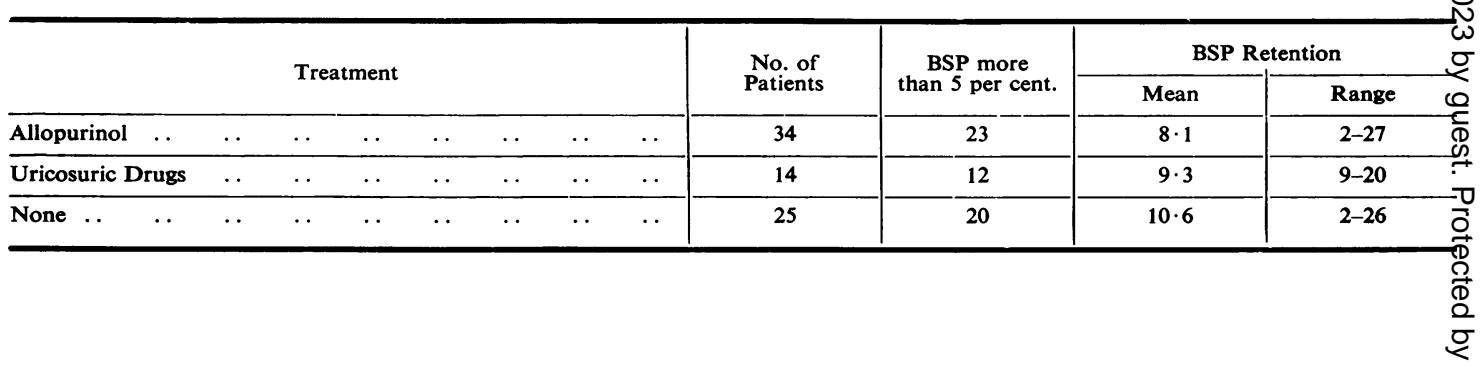


correction to our own series, we find very little difference from the uncorrected results (Table III). Though the degree of abnormality in the gouty and hyperuricaemic groups was slightly reduced, it is still significantly higher than in the control group in both cases $(\mathrm{P}<0.001$ and 0.01 respectively).

In our series there was a tendency for subjects of greatest weight to have the highest BSP retention (Fig. 2) and correlation between these two values was significant (correlation coefficient +0.44 ; $\mathbf{P}<0 \cdot 001$ ).

In eleven gouty subjects, serial determinations of weight and BSP retention were made. Six gained weight and in five of these the BSP rose. Five lost weight and in all of these the BSP fell. Lowering the serum uric acid with either allopurinol or probenecid during this period did not appear to be responsible for changes in BSP, because all the patients were so treated and neither drug was associated with a change in weight in a particular direction. In one patient, however, BSP fell from 10 to 5 per cent. despite a gain in weight. This was coincident with a small fall in serum uric acid from 6.5 to $5.5 \mathrm{mg}$./ $100 \mathrm{ml}$. associated with probenecid therapy, and it is relevant that Rundles (1966) has reported a similar fall in BSP retention ( 25 to 10 per cent.) in a nonobese gouty patient after 3 weeks' treatment with allopurinol.

Seegmiller (1966) has suggested that ideal rather than the actual body weight should be used when determining the dose of BSP for injection. We accordingly repeated the test in $\mathbf{3 5}$ gouty patients, basing the dose on ideal weight, and the results were compared with those obtained using actual weight. Using actual weight, 31 of the 35 patients showed more than 5 per cent. retention (mean $8 \cdot 7$ ), whereas using ideal weight only fourteen of the 35 were abnormal (mean 5.9). Thus, though more than half the BSP results reverted to normal when ideal weight was used, there was still a high incidence of abnormality.

It seems, therefore, that weight, though doubtless exaggerating the degree of abnormality, was not the sole cause.
Fig. 2.- Relation between BSP retention and actual body weight in gouty, asymptomatic hyperuricaemic, and control subjects.

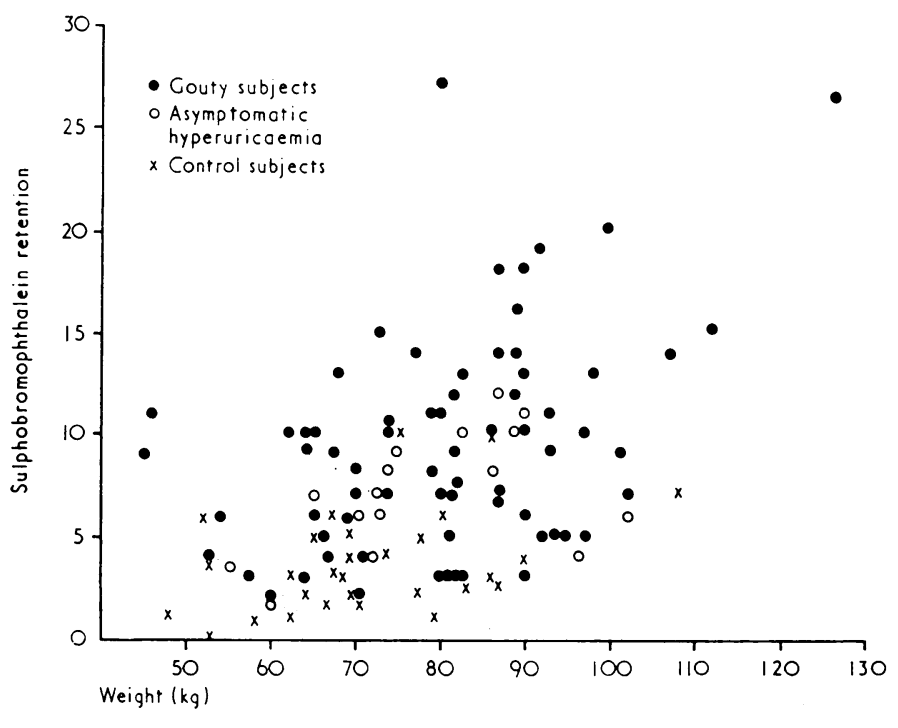

TABLE III

FINDINGS CORRECTED FOR WEIGHT OF SUBJECT

\begin{tabular}{l|c|c|c|c|c|c|c|}
\hline \multirow{2}{*}{ Diagnosis } & \multicolumn{3}{|c|}{ Uncorrected } & \multicolumn{3}{|c}{$\begin{array}{c}\text { Corrected for weight } \\
\text { after Zieve and Hill (1955) }\end{array}$} \\
\cline { 2 - 7 } & No. of Cases & & \multicolumn{2}{|c|}{ BSP Retention } \\
\cline { 2 - 7 } & & Mean & Range & $\begin{array}{c}\text { Greater than } \\
5 \text { per cent. }\end{array}$ & Mean & Retention \\
\hline Gout & 73 & $9 \cdot 2$ & $(2 \cdot 27)$ & 55 & $8 \cdot 0$ & $(0 \cdot 26)$ & 5 \\
\hline Asymptomatic Hyperuricaemia & 16 & $7 \cdot 1$ & $(2-12)$ & 12 & $6 \cdot 2$ & $(1-9)$ & 11 \\
\hline Control Subjects & 30 & $3 \cdot 5$ & $(0-10)$ & 6 & $3 \cdot 6$ & $(0-10)$ & 5 \\
\hline
\end{tabular}




\section{(B) Alcohol Intake}

Gouty patients are often heavy drinkers and BSP retention is frequently raised in cases of alcoholism (Leevy, Patrylo, and Doody, 1953). In our series there was a correlation between raised BSP retention and regular alcohol consumption (arbitrarily defined as an average daily intake of two pints of beer or two double whiskies or more) but these figures do not reach statistical significance $(0.1>\mathrm{P}>0.05)$ (Table IV). It is noteworthy that 64 per cent. of gouty subjects with raised BSP retention did not admit to regular drinking and three patients whose BSP was more than 15 per cent. were teetotal, so that if the statements made by these patients are correct alcohol cannot be solely responsible for the abnormalities.

TABLE IV

EFFECT OF ALCOHOL INTAKE ON BSP

\begin{tabular}{l|r|r}
\hline \multirow{1}{*}{ Alcohol Intake } & \multicolumn{2}{|c}{ BSP Retention } \\
\cline { 2 - 3 } & 5 per cent. or Less & Over 5 per cent. \\
\hline $\begin{array}{l}\text { Regular Drinkers } \\
\text { Non-drinkers }\end{array}$ & 3 & 20 \\
& 15 & 35 \\
\hline
\end{tabular}

\section{(C) Age}

Rafsky and Newman (1943) found that in 26 per cent. of subjects over the age of 60 years the BSP was raised. In our series, considering all non-obese non-drinking subjects studied, abnormal BSP retention was significantly more common in subjects over the age of 60 than in the rest $(0.05>P>0.02)$. Nine out of twelve (75 per cent.) over the age of 60 years had a BSP retention of greater than 5 per cent. while in the rest only seventeen out of 37 (46 per cent.) were abnormal.

However, if these three factors are excluded by eliminating all patients who were more than 10 per cent. overweight, known regular drinkers, and/or over the age of 60 , there are still significantly $(P=0.001)$ more gouty and hyperuricaemic patients with abnormal BSP retention than control subjects (Fig. 3). Eleven of seventeen gouty and three of four hyperuricaemic subjects had a raised BSP compared with only two out of sixteen controls. From this it appears that BSP retention is often raised in gout and asymptomatic hyperuricaemia irrespective of weight, known regular alcohol intake, and age.

OTHER Liver Function Tests.-Abnormal isocitric dehydrogenase (more than 10 units) was found in ten out of 66 patients with gout (15 per cent.). An abnormal result was invariably associated with a BSP of 9 per cent. or more, though the converse was

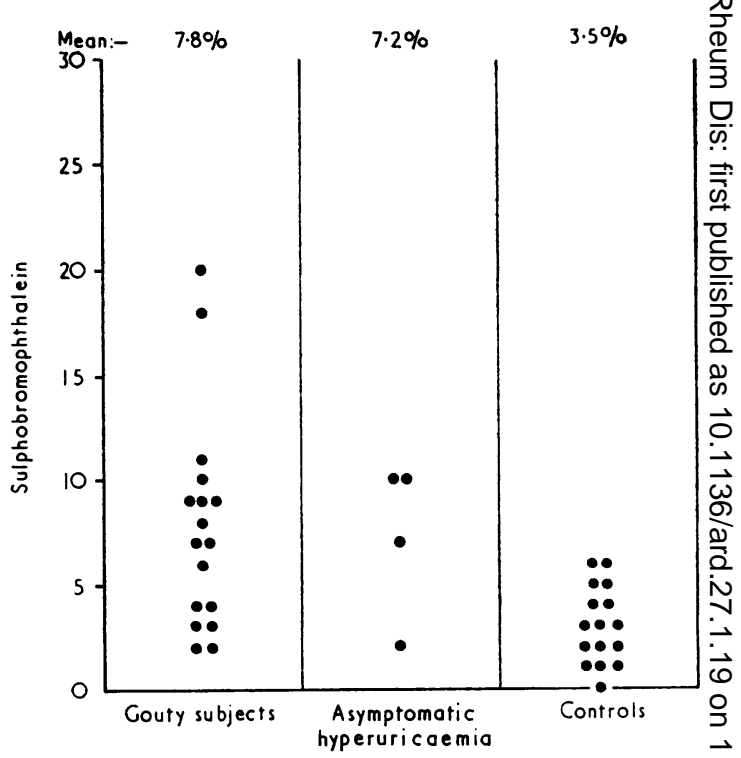

Fig. 3.-Scatter diagram of BSP results in young, lean, non-drinkin gouty, asymptomatic hyperuricaemic, and control subjects.

not true. In addition, five of the sixteen witk asymptomatic hyperuricaemia also showed abnormate ICD (two of these were associated with a norianas BSP) and two of 24 controls showed an abnormat ICD and these both had a normal BSP. The mêp ICD in three groups was $7 \cdot 6,8 \cdot 0$, and $6 \cdot 4$ unts respectively, the differences being insignifican $(\mathrm{P}=\mathbf{0} \cdot 2)$. Abnormal serum alkaline phosphatase levels (more than $13 \mathrm{KA}$ units) were found in sis out of 73 gouty subjects (excluding two patients wit known Paget's disease), in two out of sixteen with asymptomatic hyperuricaemia, and in none of the controls. The mean alkaline phosphatase in the three groups was $9 \cdot 5,9 \cdot 9$, and $7 \cdot 7 \mathrm{KA}$ unit respectively; these differences were small buf significant $(P<0.01$ and 0.05$)$.

Only marginal abnormalities were found in the other liver function tests performed and results are not given in detail.

Effect of Raising Serum Urate in Healthe SUBJECTS.-A satisfactory degree of hyperuricaemiz: was achieved in all five healthy subjects and the effects on liver function tests are shown in Table $\mathrm{K}$ (opposite).

Subject 6, who was suffering from rheumatoi\&p arthritis, was rendered hyperuricaemic only with difficulty and after raising the dose of RNA $9 \mathrm{~g}$./day. Though Subjects 1 and 2 showed a transien? slight rise, the BSP remained unaffected in the remaining subjects and it seems that under the conditions of the study there was no significarit 
TABLE V

EFFECTS OF RAISING SERUM URATE LEVELS

\begin{tabular}{|c|c|c|c|c|c|c|}
\hline Diagnosis & $\begin{array}{l}\text { Subject } \\
\text { No. }\end{array}$ & $\underset{\text { Test }}{\text { Liver Function }}$ & $\begin{array}{l}\text { Before } \\
\text { RNA }\end{array}$ & $\begin{array}{l}\text { After } 48 \text { hrs } \\
\text { RNA }\end{array}$ & $\begin{array}{c}\text { After } 1 \text { week } \\
\text { RNA }\end{array}$ & $\begin{array}{l}4 \text { days after RNA } \\
\text { Discontinued }\end{array}$ \\
\hline \multirow{5}{*}{ Normal } & 1 & $\begin{array}{l}\text { SUA } \\
\text { BSP } \\
\text { ICD } \\
\text { AP }\end{array}$ & $\begin{array}{c}6 \cdot 4 \\
10 \\
5 \\
6\end{array}$ & $\begin{array}{c}10 \cdot 1 \\
14 \\
6 \\
5\end{array}$ & 二 & $\begin{array}{c}7 \cdot 0 \\
12 \\
6 \\
7\end{array}$ \\
\hline & 2 & $\begin{array}{l}\text { SUA } \\
\text { BSP } \\
\text { ICD } \\
\text { AP }\end{array}$ & $\begin{array}{l}4 \cdot 5 \\
5 \\
6 \\
6\end{array}$ & $\begin{array}{l}9 \cdot 5 \\
7 \\
6 \\
5\end{array}$ & 二 & $\begin{array}{l}5 \cdot 4 \\
4 \\
8 \\
7\end{array}$ \\
\hline & 3 & $\begin{array}{l}\text { SUA } \\
\text { BSP } \\
\text { ICD } \\
\text { AP }\end{array}$ & $\begin{array}{l}4 \cdot 0 \\
1 \\
8 \\
4\end{array}$ & $\begin{array}{l}7 \cdot 8 \\
2 \\
6 \\
5\end{array}$ & E & $\begin{array}{l}\text { ND } \\
\text { ND } \\
\text { ND } \\
\text { ND }\end{array}$ \\
\hline & 4 & $\begin{array}{l}\text { SUA } \\
\text { BSP } \\
\text { ICD } \\
\text { AP }\end{array}$ & $\begin{array}{l}6 \cdot 7 \\
5 \\
1 \\
6\end{array}$ & $\begin{array}{c}10 \cdot 0 \\
6 \\
4 \\
5\end{array}$ & $\bar{z}$ & $\begin{array}{l}\text { ND } \\
\text { ND } \\
\text { ND } \\
\text { ND }\end{array}$ \\
\hline & 5 & $\begin{array}{l}\text { SUA } \\
\text { BSP } \\
\text { ICD } \\
\text { AP }\end{array}$ & $\begin{array}{c}6 \cdot 6 \\
4 \\
7 \\
10\end{array}$ & $\begin{array}{c}9 \cdot 5 \\
5 \\
7 \\
10\end{array}$ & 二 & $\begin{array}{l}\text { ND } \\
\text { ND } \\
\text { ND } \\
\text { ND }\end{array}$ \\
\hline $\begin{array}{l}\text { Rheumatoid } \\
\text { Arthritis }\end{array}$ & 6 & $\begin{array}{l}\text { SUA } \\
\text { BSP } \\
\text { ICD } \\
\text { AP }\end{array}$ & $\begin{array}{c}5 \cdot 1 \\
5 \\
3 \\
10\end{array}$ & $\begin{array}{l}5 \cdot 6 \\
3 \\
5 \\
\text { ND }\end{array}$ & $\begin{array}{l}6 \cdot 7 \\
4 \\
\text { ND } \\
\text { ND }\end{array}$ & $\begin{array}{l}\text { ND } \\
\text { ND } \\
\text { ND } \\
\text { ND }\end{array}$ \\
\hline
\end{tabular}

change in any of the liver function tests performed. None of the subjects experienced any adverse effect from the transient hyperuricaemia.

\section{Discussion}

The sulphobromophthalein excretion test, introduced over 40 years ago (Rosenthal and White, 1925), and later modified (Mateer, Baltz, Marion, and MacMillan, 1943), is generally regarded as the most sensitive index of liver function in the absence of jaundice. Elevation of BSP retention also occurs in cardiac failure (Felder, Mund, and Parker, 1950; Richman, Delman, and Grob, 1961), old age (Rafsky and Newman, 1943), alcoholism (Leevy and others, 1953), infections (Neale, Caughey, Mollin, and Booth, 1966), malaria (Machella, 1947), artificially-induced fever (Bradley and Conan, 1947; Hicks, Holt, Guerrant, and Leavell, 1948), obesity (Zelman, 1952), starvation (Rozental, Biava, Spencer, and Zimmerman, 1967), after extra-abdominal surgery (Tagnon, Robbins, and Nichols, 1948), and after the use of the gall-bladder contrast medium iopanoic acid "Telepaque" and the anabolic steroid drug norethandrolone "Nilivar" (Schoenfeld and Foulk, 1964). Abnormal BSP retention has also been stated to occur after exercise, in hyperthyroidism, Cushing's disease, and ulcerative colitis (Cohn, 1965).
No association has previously been recorded between raised BSP retention and gout or hyperuricaemia. There are two possible explanations for this apparent association:

(1) It is possible that gout is not infrequently accompanied by liver disease. Previous workers (Wolfson, Cohn, Levine, Rosenberg, and Hunt, 1949) have tended to discount this possibility and certainly none of our patients showed clinical signs of liver disease. Some abnormality of other liver function tests was present, however, in 25 (34 per cent.) of the patients with gout, in eight ( 50 per cent.) of those with asymptomatic hyperuricaemia, and yet in only two (6 per cent.) of the control subjects. Most of these abnormalities were minor deviations from the normal, but levels of BSP retention tended to be higher in those with abnormal tests. Apart from this, however, there was poor correlation between the different indices of liver function.

In order to elucidate this problem further we reviewed the hepatic histology in patients known to be suffering from gout who had come to post mortem at the Hammersmith Hospital in recent years. Of the eight cases examined, three showed fatty change (which was marked in two), one showed congestion, and the remainder were normal. The significance, if any, of this is uncertain. Liver 
function tests had not been performed in life in these patients.

If impairment of liver function in gout is commoner than previously suspected, a possible explanation lies in the effects of alcohol intake. In this series a relation existed between regular drinking and raised BSP retention, but did not reach statistical significance. It may be that patients drank more alcohol than they cared to admit and if this were so it could account for all the abnormalities observed.

(2) The second possible explanation is competition between BSP and uric acid for the same hepatic excretory pathway. Approximately one-third of the total uric acid excreted by the body is passed into the gastro-intestinal tract via the saliva, bile, and intestinal juices, bile itself containing uric acid in a concentration between 4 and $6 \mathrm{mg}$. per $100 \mathrm{ml}$. in non-gouty subjects (Sørensen, 1960) with an estimated total biliary excretion of about $50 \mathrm{mg}$. uric acid per day. BSP excretion can be impaired by the simultaneous injection of sodium dehydrocholate (Cantarow and Wirts, 1943; Mendeloff, Kramer, Ingelfinger, and Bradley, 1949), bilirubin, albumin, and amino-acids (Myers, 1949), and rose bengal (Cohen, Giansiracusa, and Althausen, 1953); it is conceivable that hyperuricaemia could produce the same effect. Against this, however, is the fact that in the present investigation artificially-induced hyperuricaemia failed to affect BSP retention significantly.

There is inadequate evidence whether the impairment of BSP retention in gout and asymptomatic hyperuricaemia is due to impaired liver function (possibly due to alcohol intake) or to competitive inhibition of BSP excretion by uric acid or to a combination of these two factors.

During the course of this study it has become apparent that the BSP test as commonly carried out presents a number of problems as regards dosage and the validity and interpretation of results.

Correct dosage depends on a knowledge of plasma volume which is not accurately reflected by any indirect measurement (either actual or ideal weight or surface area).

In fact there is a very wide range in the plasma volume:actual body weight relationship which must cause discrepancies between dosage and results in individual subjects. Serious errors leading to over-estimation of retention will occur in obese persons who have a relatively small plasma volume. There is no evidence, however, that gouty subjects have a lowered plasma volume to explain the abnormalities we have found in non-obese cases. For further investigation it would be necessary to improve the accuracy of the BSP test procedure, $\stackrel{\vec{\Phi}}{\bar{D}}$ either by direct measurement of plasma volume or 3 by taking multiple blood samples after injection to $\square$ establish zero-time plasma concentration by extrapolation.

Finally, as regards the upper limit of normal of BSP retention, Zieve and Hill (1955) used the same test procedure as in the present investigation to $\overline{\bar{n}}$. study 718 apparently normal men. They found a mean BSP retention of $4 \cdot 7$ per cent., S.D. $2 \cdot 7$. It is clear from these results and our own that a con-» siderable number of normal subjects have a $\mathrm{BSP}_{-}$ retention of over 5 per cent. and that this figureshould not therefore be regarded as an absolutew upper limit of normal.

\section{Summary}

A high incidence of abnormal results in the $\overrightarrow{0}$ sulphobromophthalein (BSP) retention test has been? found in a group of patients suffering from goutand another with asymptomatic hyperuricaemia.c 55 of 73 (75 per cent.) gouty subjects and twelve out of sixteen ( 75 per cent.) with asymptomatic hyperuri caemia showed more than 5 per cent. retention of BSP at 45 minutes, compared with only six out $₫ f^{\circ}$ thirty (20 per cent.) controls. Though these resunts ${ }^{\infty}$ may have been influenced by the effects of obesify alcohol intake, and age, significant differences axes still apparent after allowances have been made for these factors. Possible mechanisms for this apparento association are discussed. Attention is drawn to $\mathbb{D}$ certain inaccuracies in the BSP test as commonly $F_{0}$ performed, and in particular in the interpretation of 3 results in obese subjects.

\section{DISCUSSION}

DR. A. ST. J. Dixon (Bath): 2 or 3 years ago, a paper reported the effect of uricosuric drugs on hepatic function benemid had a suppressing effect on BSP excretion. I 3 wonder whether your measurements were made on patients taking uricosuric drugs?

DR. Grahame: We had three groups of patients with gout under supervision. One group of 34 was underos treatment with Allopurinol, fourteen were receiving uricosuric drugs, and 25 were receiving no long-term treatment at all. We found a high incidence of abnor $\omega$ mality in all three groups. It was of interest that, in the untreated group, the abnormality seemed to be greater than in the treated groups and that those on Allopurino $\bar{D}$ showed a higher incidence of abnormality than those onf? uricosuric drugs. When submitted to statistical analysis; however, there was no difference between the three groups. 
Dr. W. W. Buchanan (Glasgow): I think that in order totally to exclude the effect of obesity it would be desirable to calculate the "lean body mass" from say the tritium or antipyrine space, rather than to use the "ideal body weight". If you gave a dose of sulphobromophthalein calculated on the basis of the lean body mass and still found abnormal retention, this would greatly strengthen your thesis that there is a defect of sulphobromophthalein excretion in gout.
Dr. Grahame: The point I wanted to make earlier was that, when we excluded all the obese subjects-that is, everybody more than 10 per cent. overweight-even then we found that the differences were still significant.

Accurate dosage in the BSP test would best be achieved by measuring plasma volume by one of the standard techniques, but I doubt if it would significantly affect our results.

\section{REFERENCES}

Bell, J. L., and Baron, D. N. (1960). Clin. chim. Acta, 5, 740 (A colorimetric method for determination of isocitric dehydrogenase).

Bradley, S. E., and Conan, N. J. (1947). J. clin. Invest., 26, 1175 (Estimated hepatic blood flow and bromsulfalein extraction in normal man during the pyrogenic reaction).

Brøchner-Mortensen, K. (1941). Acta. med. scand., 106, 81 (100 gouty patients).

Cantarow, A., and Wirts, C. W. (1943). Amer. J. dig. Dis., 10, 261 (The effect of dog's bile, certain bile acids and India ink on bilirubinemia and the excretion of bromsulfalein).

Cohen, E. S., Giansiracusa, J. E., and Althausen, T. L. (1953). Gastroenterology, 25, 237 (Studies on bromsulfalein excretion. III. The simultaneous performance of the bromsulfalein and rose bengal excretion tests in individuals with normal hepatic function).

Cohn, E. M. (1965). " "Liver Function Tests and Other Diagnostic Procedures", in "Gastroenterology" ed. H. L. Bockus, 2nd ed., vol. 3, pp. 152-153. Saunders, Philadelphia.

Felder, L., Mund, A., and Parker, J. G. (1950). Circulation, 2, 286 (Liver function tests in chronic congestive heart failure).

Gibson, J. G., and Evans, W. A. (1937). J. clin. Invest., 16, 317 (Clinical studies of the blood volume. II. The relation of plasma and total blood volume to venous pressure, blood velocity rate, physical measurements, age and sex in ninety normal humans).

Henry, R. J. (1964). "Clinical Chemistry-Principles and Technics", Hoeber, New York.

Hicks, M. H., Holt, H. P., Guerrant, J. L., and Leavell, B. S. (1948). J. clin. Invest, 27, 580 (The effect of spontaneous and artificially induced fever on liver function).

Leevy, C. M., Patrylo, I., and Doody, W. (1953). Quart. J. Stud. Alcohol, 14, 568 (Hepatic abnormalities in alcoholics with delirium tremens).

Machella, T. E. (1947). Amer. J. med. Sci., 213, 81 (The relationship of bromsulphalein retention to the fever of natural $P$. falciparum malaria).

Mateer, J. G., Baltz, J. I., Marion, D. F., and MacMillan, J. M. (1943). J. Amer. med. Ass., 121, 723 (Liver function tests. A general evaluation of liver function tests, and an appraisal of the comparative sensitivity and reliability of the newer tests, with particular emphasis on the cephalin-cholesterol floculation test, the intravenous hippuric acid test and an improved bromsulphalein test with a new normal standard).

Mendeloff, A. I., Kramer, P., Ingelfinger, F. J., and Bradley, S. E. (1949). Gastroenterology, 13, 222 (Studies with bromsulfalein II. Factors altering its disappearance from the blood after a single intravenous injection).

Myers, J. D. (1949). J. clin. Invest., 28, 801 (Observations on the excretion of bromsulphalein).

Neale, G., Caughey, D. E., Mollin, D. L., and Booth, C. C. (1966). Brit. med. J., 1, 382 (Effects of intrahepatic and extrahepatic infection on liver function).

Nugent, C. A., and Tyler, F. H. (1959). J. clin. Invest., 38, 1890 (The renal excretion of uric acid in patients with gout and in nongouty subjects.)

Rafsky, H. A., and Newman, B. (1943). Amer. J. dig. Dis., 10, 66 (Liver function tests in the aged (The serum cholesterol partition, bromsulphalein, cephalin-flocculation and oral and intravenous hippuric acid tests) ).

Richman, S. M., Delman, A. J., and Grob, D. (1961). Amer. J. Med., 30, 211 (Alterations in indices of liver function in congestive heart failure with particular reference to serum enzymes).

Rosenthal, S. M., and White, E. C. (1925). J. Amer. med. Ass., 84, 1112 (Clinical application of the bromsulphalein test for hepatic function).

Rozenthal, P., Biava, C., Spencer, H., and Zimmerman, H. (1967). Amer. J. dig. Dis., n.s. 12, 198 (Liver morphology and function tests in obesity and during total starvation).

Rundles, R. W. (1966). Ann. rheum. Dis., 25, 645 (Primary hyperuricaemia and gout: discussionliver function). 
Seegmiller, J. E. (1966). Ibid., 25, 645 (Primary hyperuricaemia and gout : discussion-liver function). Schoenfeld, L. J., and Foulk, W. T. (1964). J. clin. Invest., 43, 1419 (Studies of sulfobromophthalein sodium (BSP) metabolism in man. II. The effect of artificially induced fever, norethandrolone (Nilevar) and iopanoic acid (Telapague) ).

Scott, J. T., Hall, A. P., and Grahame, R. (1966). Brit. med.J., 2, 321 (Allopurinol in treatment of gout).

Seligson, D., Marino, J., and Dodson, E. (1957). Clin. Chem., 3, 638 (Determination of sulfobromophthalein in serum).

Sherlock, S. (1963). "Diseases of the Liver and Biliary System", 3rd ed. Blackwell, Oxford.

Sørensen, L. B. (1960). Scand. J. clin. Lab. Invest., 12, Suppl. 54 (The elimination of uric acid in man studied by means of $\mathrm{C}^{\mathbf{1 4}}$-labelled uric acid).

Tagnon, H. J., Robbins, G. F., and Nichols, M. P. (1948). New Engl. J. Med., 238, 556 (The effect of surgical operations on the bromsulfalein-retention test).

Wolfson, W. Q., Cohn, C., Levine, R., Rosenberg, E. F., and Hunt, H. D. (1949). Ann. intern. Med., 30, 598 (Liver function and serum protein structure in gout).

Zelman, S. (1952). Arch. intern. Med., 90, 141 (The liver in obesity).

Zieve, L., and Hill, E. (1955). Gastroenterology, 28, 766 (An evaluation of factors influencing the discriminative effectiveness of a group of liver function tests. II. Normal limits of eleven representative hepatic tests).

La rétention de la bromosulfophtaléine au cours de la goutte et de l'hyperuricémie asymptomatique.

\section{RÉSUMÉ}

On a trouvé une forte proportion de résultats anormaux après épreuve à la BSP chez des malades ayant la goutte et chez d'autres ayant une hyperuricémie asymptomatique. Cinquante cinq des 73 goutteux $(75 \%)$ et 12 des 16 sujets ayant une hyperuricémie asymptomatique $(75 \%)$ accusèrent une rétention de BSP supérieure à 5 pour cent au bout de 45 minutes; une rétention similaire ne fut obtenue que chez 6 des 30 témoins $(20 \%)$. Bien que ces résultats aient pu être influencés par l'obésité, l'ingestion d'alcool ou l'âge, des différences significatives sont encore apparentes, compte tenu de ces facteurs. On discute le mécanisme possible de cette apparente corrélation. On attire l'attention sur le caractère quelque peu imprécis de l'épreuve à la BSP telle qu'elle est pratiquée communément, surtout en ce qui concerne l'interprétation des résultats chez les obèses.
La retención de la bromosulfoftaleina en el curso de la gota $y$ de la hiperuricemia asintomática.

\section{Sumario}

Se encontró una fuerte proporción de resultadoș anormales en los tests de retención de la bromosulfo ftaleina (BSP en el texto inglés) en enfermos con gota otros con uricemia asintomática. $55(75 \%)$ de los gु3 gotosos y $12(75 \%)$ de los 16 sujetos con hiperuriceraia asintomática acusaron una retención de BSP superio a $5 \%$ a los 45 minutos; una retención similar se obse sólo en 6 de los 30 testigos $(20 \%)$. La obesidad, e alcoholismo o la edad pudieron haber afectado estoso resultados, sin embargo, aunque se tenga cuenta de estošn factores, las diferencias aparecen significativas. Se discuteD el mecanismo posible de esta correlación aparente. Se llama atención al hecho de que el test de bromosulfo- $\overrightarrow{\widehat{\sigma}}$ ftaleina en uso común no es muy exacto, en particular 3 cuando se quiere interpretar los resultados en las personas obesas. 